\title{
IDENTIFICATION OF 120 kD AND 30 kD RECEPTORS FOR HUMAN CORONAVIRUS OC43 IN CELL MEMBRANE PREPARATIONS FROM NEWBORN MOUSE BRAIN
}

\author{
Arlene R. Collins \\ Department of Microbiology \\ State University of New York At Buffalo \\ Buffalo, New York
}

\begin{abstract}
A biotinylated virus overlay was used to identify a $120 \mathrm{kD}$ virus-binding molecule in dissociated newborn mouse brain $(\mathrm{nmb})$ cell suspensions after separation of the proteins by polyacrylamide gel electrophoresis, electroblotting, and blockage of non-specific binding sites. The virus-binding molecule was not detected in adult mouse brain cell suspensions. Mannose- and glucose-rich glycoproteins from nmb cell membranes were selected by ConA-Sepharose (Pharmacia) chromatography. A $30 \mathrm{kD}$ virus-binding molecule was eluted by $0.2 \mathrm{M}$ alpha-methyl-D-mannoside. O-linked sialic acid, a receptor component, was identified in the eluate.
\end{abstract}

\section{INTRODUCTION}

OC43 is a human respiratory virus in the Coronaviridae family which has been adapted to grow in suckling mice and cause a lethal neurotropic infection. Infected mice display a selective tropism toward neurons ${ }^{1}$. Astrocytes also are susceptible to infection in vitro but do not produce infectious virus ${ }^{2}$. Cultured human embryo brain cells can be infected as well as the human astroglioma cell line, $\mathrm{U} 87-\mathrm{MG}^{3}$. A study of the molecular basis of murine neuronal cell susceptibility was initiated to find a tissue specific receptor for the virus.

\section{MATERIALS AND METHODS}

Whole brain was removed from 203 litters of euthanized, 4, 7, and 10 day old $\mathrm{C} 57 \mathrm{BL} / 6 \mathrm{~K}$ mice. The tissue was dissociated by passage through a $202 \mu \mathrm{m}$ pore size nylon 
mesh, washed 5 times in $0.1 \mathrm{M}$ phosphate buffered saline, $\mathrm{pH} 7.2$ (PBS), and lysed in lysis buffer (20 mM Tris-HCL, pH 8.0, $1 \mathrm{nM} \mathrm{Na-EDTA,} 150 \mathrm{mM} \mathrm{NaCl}, 1 \mathrm{mM}$ phenylmethylsulfonylfluoride, $1 \%$ nonidet $\mathrm{p}-40,0.02 \% \mathrm{NaAzide})$. Insoluble material was removed by centrifugation at $100,000 \times \mathrm{g}$ for $1 \mathrm{~h}$. Cell lysates were stored at $-70^{\circ} \mathrm{C}$.

Human coronavirus OC43, obtained from G. Gerna, was propagated and assayed by plaque formation in MRC- 5 cells ${ }^{4}$. For biotinylation, supernatant virus was harvested from RD cells, and concentrated 100 -fold by ultracentrifugation and mixed with an equal volume of $0.1 \mathrm{mg} / \mathrm{ml} \mathrm{NHS}$-Biotin (Sigma) in PBS for $10 \mathrm{~min}$ at $\mathrm{O}^{\circ} \mathrm{C}$, then dialyzed overnight against 100 volumes of cold PBS, changing the buffer once. Biotinylated virus was titrated for infectivity and stored at $-70^{\circ} \mathrm{C}$.

Cell lysates (3-15 $\mu \mathrm{m}$ volumes) were separated on 10\% SDS-Page cells and electroblotted to Immobilon (Millipore). The substrate was blocked with $5 \%$ bovine serum albumin (BSA) in $0.01 \mathrm{M}$ Tris-HCL, $\mathrm{pH} 7.5,0.15 \mathrm{M} \mathrm{NaCl}$ (TBS) for $30 \mathrm{~min}$ at $37^{\circ} \mathrm{C}$ and $0.1 \mathrm{M}$ alpha-methyl-D-mannoside in PBS for $20 \mathrm{~min}$ at $26^{\circ} \mathrm{C}$ to reduce nonspecific binding of avidin to lectins. To detect virus binding proteins, the blot was probed with biotinylated OC43 virus (512 hemagglutinating units) in PBS for $1 \mathrm{~h}$ at $26^{\circ} \mathrm{C}$ and washed three times in TBS- $0.1 \%$ BSA. Bound virus was visualized by incubation with avidin conjugated to horseradish peroxidase (HRP) at 1:1000 dilution in TBS-0.1\% BSA and developed in TBS containing $0.5 \mathrm{mg} / \mathrm{ml}$ 4-chloro-1-naphthol and $0.03 \% \mathrm{H}_{2} \mathrm{O}_{2}$. As controls for specificity of the reaction, the substrate was probed with avidin HRP alone, or unbiotinylated virus, rabbit anti-OC43 antibody (1:2000), and goat anti-rabbit IgG conjugated to HRP (1:1000), or rabbit anti-carcinoembryonic antigen (DAKO, 1:200) and the secondary antibody. Probing with antibody gave a high background.

Mouse brain cell lysate was dialyzed overnight against 200 volumes of PBS. The dialysate was mixed with an equal volume of ConA-Sepharose $(25 \%)$ in binding buffer $(20 \mathrm{mM}$ Tris- $\mathrm{HCl}, \mathrm{pH} 7.4$, p. $5 \mathrm{M} \mathrm{NaCl})$ and incubated for $1.5 \mathrm{~h}$ at $4^{\circ} \mathrm{C}$ with gentle rocking. After centrifugation at $300 \mathrm{x}$ g for $1 \mathrm{~min}$, the supernatant was saved and the procedure was repeated once. To elute bound glycoproteins, the ConA-Sepharose was resuspended in two volumes of PBS containing 0.2 $\mathrm{M} \alpha$-methyl-D-mannoside, and left overnight at $4^{\circ} \mathrm{C}$.
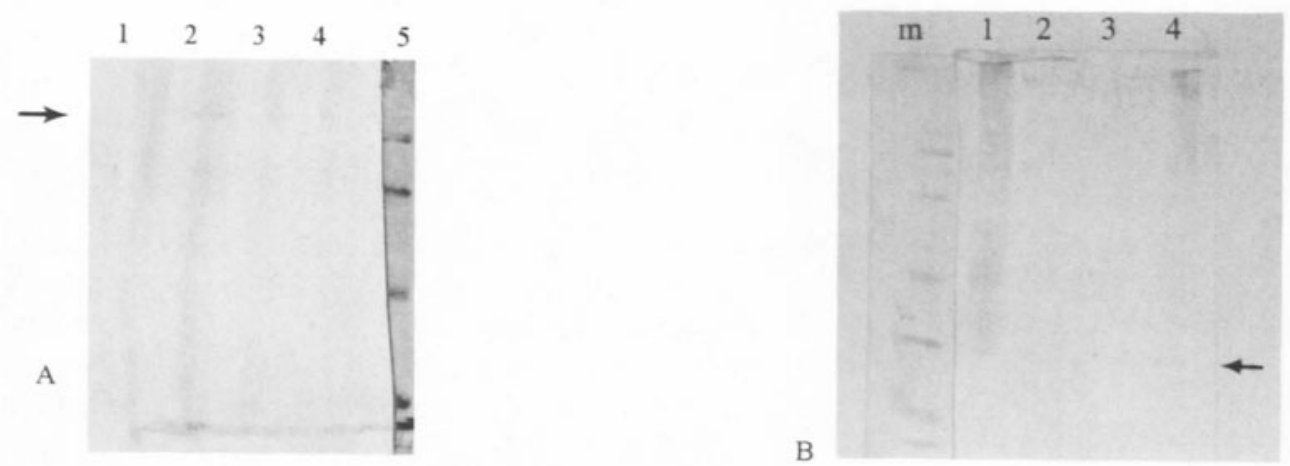

Figure 1. Identification of the OC43 receptor in mouse brain cell lysates by the solid phase virus binding assay using biotınylated virus (A) Lanes 1-4 seven-day-old mouse brain cell lysate at 15, 10, 6, and 3 ml volumes. Lane 5 molecular weight markers, from the top 97, 66, 45, and $33 \mathrm{kD}$ bands respectively (B) Lane 1 molecular weight markers $116,97,66,45$, and $33,21 \mathrm{kD}$ Lane 2 four-day-old mouse brain lysate after dialysis against PBS, $10 \mathrm{ml}$ Lane 3 and 4 First and second supernatant from ConA absorption, $10 \mathrm{ml}$ Lane 5 Eluate from ConA elution with $02 \mathrm{M} \mathrm{B}$ a-methyl-D-mannoside, $10 \mathrm{ml}$ Arrow indicates the $30 \mathrm{kD}$ receptor. 
Table 1. Inhibition of viral esterase cleavage of

pNPA by neuronal membrane glycoproteins

\begin{tabular}{lc}
\hline Sample $^{\mathrm{a}}$ & Rate $^{\mathrm{b}}$ at OD405 \\
\hline conc OC43 & 0.4005 \\
conc OC43 + eluted fraction & 0.0337 \\
\hline${ }^{\mathrm{a}} 20 \mu \mathrm{l}$ of each component in $0.5 \mathrm{ml}$ PBS containing $100 \mu \mathrm{g}$ \\
pNPA \\
bunits per min; 10 min total time O-sialic acid content was \\
measured by reduction in absorbance at OD405 due to \\
sialated glycoproteins in competition with \\
para-nitrophenylacetate (pNPA) for viral esterase
\end{tabular}

\section{RESULTS AND DISCUSSION}

Since OC43 virus selectivity infects neurons, dissociated whole brain cell membrane lysate from 7-day-old mice was probed for biotinylated virus binding in the solid phase assay. Shown by Figure 1A, a single receptor was visible at molecular weight $120 \mathrm{kD}$. When the substrate was probed with antibody to carcinoembryonic antigen, the $120 \mathrm{kD}$ receptor detected by unbiotinylated virus, appeared to be unrelated. This unique receptor may explain the selective tropism of the virus for neural cells. Further work must be done using embryonic or immature human neurons for comparison.

Since ConA adsorbs HIV-1 envelope glycoproteins which subsequently are able to bind antibodies to all of the conformational epitopes of gp $120^{5}$, mouse brain glycoproteins from 4-day-old mice, released after absorption to ConA-Sepharose, were probed with biotinylated virus in the solid phase assay. Figure $1 \mathrm{~B}$ shows that the eluted fraction contained a $30 \mathrm{kD}$ receptor molecule. The eluate contained glycoproteins selected during adsorption in $0.5 \mathrm{M} \mathrm{NaCl}$ binding buffer. The eluted glycoproteins may be in a conformation which is more easily recognized by the virus and should be useful for molecular and immunological analysis. The dialysate prior to adsorption no longer displayed the single $120 \mathrm{kD}$ receptor but contained multiple bands of reactivity. This was probably due to dissociation of the receptor following removal of the detergent. Dialysis replaced $\mathrm{Mn} 2+$ and $\mathrm{Ca} 2+$ which are essential for ConA binding. No specific virus binding activity was detected in the supernatant binding buffer after ConA adsorption.

The eluate was further tested for $\mathrm{O}$-sialic acid content in a substrate completion assay for the viral esterase. In the presence of eluate fraction, the rate of esterase cleavage of pNPA was reduced $>90 \%$ indicating that a competing substrate was being cleaved.

The assistance of Dr. Roger K. Cunningham in collecting newborn mice and of Jeanette McGuire in preparing the manuscript is gratefully acknowledged.

\section{REFERENCES}

1. Pearson, J., Mims, C.A. Selective vulnerability of neural cells and age-related susceptibility to OC43 virus in mice. Archiv Virol 1983;77:109-118

2. Pearson, J., Mims, C A. Differential susceptibility of cultured neural cells to the human coronavirus OC43 J Virol 1985,53·1016-1019

3. Collins, A.R., Sorensen, O. Regulation of viral persistence in human glioblastoma and rhabdomyosarcoma cells infected with coronavirus OC43. Microb Path 1986;1·573-583 
4 Collins, A R HLA class I antigen serves as a receptor for human coronavirus OC43 Immunol Invest 1993,22 95-103

5 Robinson, JE, Holton, S, Liu, J, McMurdo, H, Muciano, A, Gohd, R A novel enzyme-linked immunosorbent assay (ELISA) for the detection o antibodies to HIV-1 envelope glycoproteins based on immobilization of viral glycoproteins in microtiter wells coated with Con-A Immunol Meth 1990,132 63-71

6 Pfleiderer, M, Routledge, E, Siddell, S G Functional analysis of the coronavirus MHV-JHM surface glycoproteins in vaccinıa virus recombinants Adv Virus Res 1990,276 21-31 